\title{
ANALISIS INVENTORY TURN OVER DALAM MENINGKATKAN PROFITABILITAS PADA MATAHARI DEPARTMENT STORE TBK
}

\author{
Refi Sandria Oktapiadi \\ Kokom Komariah \\ Dicky Jhoansyah \\ Fakultas Ilmu Administrasi dan Humaniora, \\ Universitas Muhammadiyah Sukabumi \\ refisandria@gmail.com) \\ ko2mpuspa@ummi.ac.id \\ dicky.jhoansyah@ummi.ac.id
}

\begin{abstract}
Inventory turnover is an important thing that must be considered for each company, how much inventory is rotating in one period. Because the more frequent inventory turnover, the more profit will be generated. The purpose of this study is to find out the Inventory Turn over analysis in increasing profitability at Matahari Department Store Tbk (LPPF) which is listed on the Indonesia Stock Exchange (IDX) for the period 2013 to 2017. This data uses secondary data obtained from www.idx.co .id. The results of this study have fluctuations in sales from 2013 to 2017. Which shows that inventory turnover at Matahari Department Store Tbk (LPPF) is less optimal and unstable so that it influences the ability of profits generated by the company.
\end{abstract}

Keywords: Inventory Turn Over, Profitability

\section{PENDAHULUAN}

Analisis Laporan keuangan merupakan suatu proses penelitian laporan keuangan yang bertujuan untuk memprediksi kondisi keuangan perusahaan yang hasilnya untuk menjadi bahan evaluasi yang telah dicapai perusahaan pada masa lalu dan masa sekarang. Dimana jika hasil evaluasi dari kondisi keuangan perusahaan terlihat baik itu menunjukkan bahwa tujuan utama perusahaan tercapai. Kondisi keuangan perusahaan dapat dilihat dari semakin tingginya perputaran persediaan barang maka semakin baik bagi perusahaan dalam menghasilkan keuntungan atau profit. Beberapa rasio yang dapat digunakan untuk mengetahui kondisi perusahaan tersebut dapat dilakukan dengan cara menggunakan rasio profitabilitas dan rasio perputaran persediaan (inventory turnover).

Rasio profitabilitas adalah rasio untuk menilai kemampuan perusahaan untuk mencari keuntungan yang ditunjukan dalam hal ini yakni pada penjualan dan pendapatan yang menghasilkan laba. Laba atau profit adalah hal yang sangat penting untuk mempertahankan kelangsungan hidup perusahaan. Semakin tinggi profit atau laba yang diperoleh diharapkan perusahaan akan tumbuh berkembang serta mampu bersaing dengan perusahaan lain. Untuk mengetahui bagaimana perusahaan dalam meghasilkan profit atau laba adalah dengan menggunakan perhitungan rasio profitabilitas.

Rasio perputaran pesediaan (inventory turn over ratio) merupakan salah satu jenis dari rasio aktivitas yang digunakan untuk 
mengukur berapa kali dana yang tertanam dalam persediaan akan berputar dalam satu periode dan berapa lama (dalam hari) rata-rata persediaan tersimpan digudang hingga akhirnya terjual. Rasio perputaran persediaan dihitung sebagai hasil bagi anatara harga pokok penjualan dengan rata-rata persediaan. Semakin tinggi rasio perputaran persediaan menunjukkan bahwa lamanya penjualan persediaan barang dagang semakin cepat, karena persediaan barang dagang dapat dijual dengan relatif semakin singkat sehingga hal ini baik bagi perusahaan untuk memperoleh dana yang tertanam dalam persediaan barang dagang dapat segera dicairkan.

Salah satu perusahaan dagang yakni Industri fashion memiliki peluang bisnis yang sangat menguntungkan, setelah bidang kuliner. Ini dapat dibuktikan dengan minat masyarakat Indonesia yang besar terhadap fashion karena ingin berpenampilan menarik dan stylist mengikuti perkembangan tren fashion yang sedang berkembang. Industri fashion juga merupakan ujung rantai dari industri tekstil yang memiliki nilai tambah tinggi dan sangat berperan penting dalam perekonomian nasional. Peranan tersebut sudah terlihat dari besarnya kontribusi industri fashion terhadap devisa negara, PDB nasional dan penyerapan tenaga kerja. Berdasarkan data Badan Pusat Statistik, nilai ekspor produk fashion pada 2015 mencapai USD12,11 miliar atau setara Rp162,4 triliun (estimasi kurs Rp13.410/ USD), dengan pasar utama Amerika Serikat, Eropa dan Jepang. Selanjutnya, kontribusi industri fashion terhadap PDB nasional sebesar $1,21 \%$. Dengan jumlah tersebut, industri fashion merupakan potential market bagi para pengusaha baik dari luar negeri maupun dalam negeri.

Perusahaan yang bergerak pada bidang industri fashion di bursa efek Indonesia salah satunya adalah Matahari Department Store Tbk (LPPF). Didirikan tanggal 1 April 1982 dengan nama PT Stephens Utama International Leasing Corp dan mulai beroperasi secara komersial pada tahun 1982 Perusahaan ini tercatat pada Bursa Efek Indonesia dimulai pada tahun 1989. Matahari Department Store Tbk ini berkantor pusat di Menara Matahari Lantai 15, Jl. Bulevar Palem Raya No. 7, Lippo Karawaci 1200, Tangerang 15811 - Indonesia.

Sehingga dengan seiring meningkatnya pasar pada industri kecantikan, Perusahaan yang digunakan penulis yaitu Matahari Department Store Tbk yang dalam pelaksanaan perusahaan belum mendapatkan laba yang optimal dikarenakan belum mengimplementasikan analisis perputaran persediaan (inventory turnover).

Berdasarkan uraian masalah diatas, penulis tertarik untuk melakukan penelitian dengan judul "Analisis Inventory Turn Over dalam meningkatkan Profitabilitas pada Matahari Department Store Tbk"

\section{TINJAUAN PUSTAKA \\ Laporan Keuangan}

Menurut Munawir (2007) "Laporan Keuangan merupakan alat yang sangat penting untuk memperoleh informasi sehubungan dengan posisi keuangan dan hasil-hasil yang telah dicapai oleh perusahaan yang bersangkutan".

Menurut Irham Fahmi (2012) "Laporan keuangan merupakan suatu informasi yang menggambarkan kondisi keuangan suatu perusahaan, dan lebih jauh informasi tersebut dapat dijadikan sebagai gambaran kinerja keuangan perusahaan tersebut".

Menurut Sofyan Syafri (2016)" Laporan Keuangan menggambarkan kondisi keuangan dan hasil usaha suatu perusahaan pada saat tertentu atau jangka waktu tertentu".

Menurut Jumingan (2009) Laporan keuangan merupakan hasil tindakan pembuatan ringkasan data keuangan perusahaan. laporan keuangan ini disusun dan ditafsirkan untuk kepentingan manajemen dan pihak lain yang menaruh perhatian atau mempunyai kepentingan 
dengan data keuangan perusahaan.

Berdasarkan pendapat para ahli tersebut maka dapat disimpulkan bahwa laporan keuangan adalah alat penting suatu perusahaan dari hasil tindakan pembuatan ringkasan data keuangan yang berisikan penggambaran kondisi keuangan perusahaan.

\section{Tujuan Laporan Keuangan}

Menurut Standar Akuntansi Keuangan (Ikatan Akuntansi Indonesia, 2007) tujuan laporan keuangan adalah menyediakan informasi yang menyangkut posisi keuangan, kinerja serta perubahan posisi suatu perusahaan yang bermanfaat bagi sejumlah besar pemakai dalam pengambilan keputusan ekonomi.

Menurut Irham Fahmi (2012) "Tujuan laporan keuangan adalah untuk memberikan informasi kepada pihak yang membutuhkan tentang kondisi suatu perusahaan dari sudut angka-angka dalam satuan moneter"

Menurut Jumingan (2009:4) Laporan keuangan yang disusun guna memberikan informasi kepada berbagai pihak terdiri atas neraca, laporan laba rugi, laporan bagian laba yang ditahan atau laporan modal sendiri, dan laporan perubahan posisi keuangan atau laporan sumber dan pengunaan dana.

Sedangkan menurut Kasmir (2012) berikut ini beberapa tujuan pembuatan atau penyusunan laporan keuangan yaitu : 1. Memberikan informasi tentang jenis dan jumlah aktiva (harta) yang dimiliki perusahaan pada saat ini; 2 . Memberikan informasi tentang jenis dan jumlah kewajiban dan modal yang dimiliki perusahaan pada saat ini; 3. Memberikan informasi tentang jenis dan jumlah pendapatan yang diperoleh pada suatu periode tertentu; 4 . Memberikan informasi tentang jumlah biaya dan jenis biaya yang dikeluarkan perusahaan dalam suatu periode tertentu; 5. Memberikan informasi tentang perubahan-perubahan yang terjadi terhadap aktiva, pasiva, dan modal perusahaan; 6 . Memberikan informasi tentang kinerja manajemn perusahaan dalam suatu periode; 7. Memberikan informasi tentang catatn- catatan atas laporan keuangan; 8. Informasi keuangan lainnya.

Berdasarkan pendapat para ahli tersebut maka dapat disimpulkan bahwa laporan keuanganadalahangkaangkayang berisikan berbagai informasi yang menggambarkan kondisi suatu perusahaan, dimana informasi tersebut bermanfaat bagi beberapa pihak yang membutuhkan.

\section{Analisis Rasio}

Menurut Sofyan Syafri (2016) "Rasio keuangan adalah angka yang diperoleh dari hasil perbandingan dari satu pos laporan keuangan dengan pos lainnya yang mempunyai hubungan yang relevan dan signifikan (berarti)".

Menurut Jumingan (2009) "Rasio dalam analisis laporan keuangan adalah angka yang menunjukkan hubungan antara suatu unsur dengan unsur lainnya dalam laporan keuangan tersebut dinyatakan dalam bentuk matematis yang sederhana".

Menurut Herry (2012), Analisis rasio merupakan salah satu alat analisis keuangan yang paling popular dan banyak digunakan. Meskipun perhitungan rasio hanyalah merupakan operasi aritmatika sederhana, namun hasilnya memerlukan interpretasi yang tidak mudah.

Menurut Munawir (2002) Rasio menggambarkan suatu hubungan atau perimbangan (mathematical relationship) antara suatu jumlah tertentu dengan jumlah yang lain, dan dengan menggunakan alat analisa berupa ratio ini akan dapat menjelaskan atau memberi gambaran kepada penganalisa tentang baik atau buruknya keadaan atau posisi keuangan suatu perusahaan terutama apabila angka ratio tersebut dibandingkan dengan angka ratio pembanding yang digunakan sebagai standard.

Menurut Herry (2015) "Rasio keuangan didisain untuk memperlihatkan 
hubungan antara item item pada laporan keuangan (neraca dan laporan Rugi-laba). Ada 5 jenis rasio keuangan : Leverage ratios, memperlihatkan berapa hutang yang digunakan perusahaan; Liquidity ratios, mengukur kemampuan perusahaan untuk memenuhi kewajiban-kewajiban yang jatuh tempo; Efficiency atau Turnover atau Asset Management ratios, mengukur seberapa efektif perusahaan mengelola aktivanya; Profitability ratios, mengukur kemampuan perusahaan menghasilkan laba; Marketvalue ratios, memperlihatkan bagaimana perusahaan dinilai oleh investor di pasar modal;

Berdasarkan pendapat para ahli diatas maka dapat disimpulkan bahwa Analisis Rasio adalah rasio berupa angka yang menggambarkan adanya hubungan antara satu unsur ke unsur yang lain.

Menurut harmono (2011) analisis rasio keuangan dapat diklasifikasikan ke dalam lima aspek rasio keuangan perusahaan, yaitu (1) rasio likuiditas, (2) rasio aktivitas, (3) rasio profitabilitas, (4) rasio solvabilitas (rasio leverages), dan (5) rasio nilai perusahaan.

\section{Rasio Aktivitas}

Menurut Harmono (20117) Rasio aktivitas adalah rasio keuangan perusahaan yang mencerminkan perputaran aktiva mulai dari kas dibelikan persediaan, untuk perusahaan manufaktur persediaan tersebut diolah sebagai bahan baku sampai menjadi produk jadi kemudian dijual baik secara kredit maupun tunai yang pada akhirnya kembali menjadi kas lagi.

Menurut Sofyan Syafri (2016:308) "Rasio aktivitas ini mengggambarkan aktivitas yang dilakukan perusahaan dalam menjalankan operasinya baik dalam kegiatan penjualan, pembelian dan kegiatan lainnya".

Menurut Kasmir (2015) "Rasio aktivitas (activity ratio) merupakan rasio yang digunakan untuk mengukur efektivitas perusahaan dalam menggunakan aktiva yang dimilikinya".
Berdasarkan pendapat para ahli diatas maka dapat disimpulkan bahwa Rasio aktivitas adalah rasio keuangan yang menggambarkan aktivitas perusahaan serta berfungsi dalam pengukuran suatu perusahaan dalam menggunakan aktiva yang dimiliki.

Menurut kasmir (2015) berikut ini adalah beberapa tujuan yang hendak dicapai perusahaan dari pengunaan rasio aktivitas antara lain: untuk mengukur berapa lama penagihan piutang selama satu periode atau berapa kali dana yang ditanam dalam piutang ini berputar dalam satu periode; untuk mengitung hari rata-rata penagihan piutang dimana hasil perhitungan ini menunjukkan jumlah hari (berapa hari) piutang tersebut rata rata tidak dapat ditagih; untuk menghitung berapa hari ratarata sediaan tersimpan dalam gudang; Untuk mengukur berapa kali dana yang ditanamkan dalam modal kerja berputar dalam satu periode atau berapa penjualan yang dapat dicapai oleh setiap modal kerja yang digunakan; untuk mengukur berapa kali dana yang ditanamkan dalam aktiva tetap berputar dalam satu periode; untuk mengukur pengunaan semua aktiva perusahaan dibandingkan penjualan.

\section{Jenis-Jenis Rasio Aktivitas}

Menurut Kasmir (2015) berikut ini ada beberapa jenis rasio aktivitas yang dirangkum dari beberapa ahli keuangan, yaitu: perputaran piutang (Receivable Turn Over), hari rata-rata penagihan piutang (Days of Receivable), perputaran sediaan (Inventory Turn Over), hari rata-rata penagihan sediaan (Days of Inventory), perputaran modal kerja (Working Capital Turn Over), perputaran aktiva tetap (Fixed Assets Turn Over, perputaran aktiva (Assets Turn Over).

Menurut James dan John (2005) Jenis Rasio Aktivitas yakni: Aktivitas piutang, Skedul Umur Piutang, Aktivitas utang, Aktivitas persediaan, Siklus Operasi vs Siklus Kas, Pemikiran kedua atas Likuiditas 
Aldine, dan Perputaran total aktiva.

Berdasarkan pendapat para ahli diatas maka dapat disimpulkan bahwa jenis rasio aktivitas terdiri dari Aktivitas piutang, Skedul Umur Piutang, Aktivitas utang, perputaran sediaan (Inventory Turn Over), hari ratarata penagihan sediaan (Days of Inventory), perputaran modal kerja (Working Capital Turn Over), perputaran aktiva tetap (Fixed Assets Turn Over, perputaran aktiva (Assets Turn Over).

\section{Persediaan}

Pada umumnya persediaan merupakan salah satu jenis aktiva lancar yang terdapat pada barang-barang perusahaan yang tujuannya untuk dijual dalam suatu periode usaha tertentu, persediaan juga memiliki peran penting untuk dapat menentukan operasi perusahaan berjalan dengan lancar.

Persediaan menurut Moh Benny Alexandri (2009) mengemukakan bahwa sebagai berikut:

Persediaan adalah suatu aktiva yang meliputi barang-barang milik perusahaan dengan maksud untuk dijual dalam suatu periode usaha tertentu, atau persediaan barang-barang yang masih dalam pengerjaan atau proses produksi, ataupun persediaan barang-barang yang masih dalam pengerjaan atau proses produksi, ataupun persediaan bahan baku yang menunggu penggunaannya dalam suatu proses produksi.

Adapun pendapat Elwood S. Buffa dalam buku manajemen keuangan bisnis dijelaskan sebagai berikut:

Ditinjau dari awal proses produksi sampai dengan penyaluran ke pihak pengecer, persediaan bahan atau barang mempunyai peranan yang penting sesuai dengan tahapan operasi dalam perusahaan. Artinya persediaan bahan baku berperan penting dalam proses produksi; sedangkan persediaan barang jadi berperan penting untuk disimpan di gudang atau di pihak pengecer.

Sedangkan Menurut Hery (2012) dalam jurnal menyatakan bahwa sebagai berikut: Persediaan di klasifikasikan menurut perusahaannya yaitu persediaan untuk perusahaan dagang dan persediaaan unttuk perusahaan manufaktur. Dalam perusahaan dagang, persediannya dikategorikan sebagai barang dagangan, dimana barang dagangan tersebut dimiliki oleh perusahaan menufaktur, persediannya belum siap untuk dijual dan perlu diolah terlebih dahulu.

Berdasarkan beberapa definisi di atas, bahwa dapat disimpulkan persediaan yang terdapat pada perusahaan ada tiga jenis persediaan, persediaan produk setengah jadi merupakan persediaan yang masih berada dalam proses produksi lebih lanjut, persediaan bahan baku merupakan persediaan yang digunakan dan diperlukan perusahaan dalam proses produksi, dan persediaan produk jadi merupakan persediaan yang siap untuk dijual pada pelanggan atau konsumen.

\section{Perputaran Persediaan (Inventory Turn Over)}

Perputaran persediaan merupakan aktivitas perusahaan yang sangat penting di pergunakan dan diperhitungkan, karena untuk dapat mengetahui efisiensi biaya yang berguna dalam mendapatkan keuntungan atau laba yang besar. Sebagaimana dikemukakan oleh Kasmir (2015) menyatakan bahwa sebagai berikut:

Perputaran persediaan merupakan rasio yang digunakan untuk megukur berapa kali dana yang ditanam dalam sediaan (inventory) ini berputar dalam suatu periode. Rasio ini dikenal dengan nama rasio perputaran persediaan (inventory turn over). Dapat diartikan pula bahwa perputaran sediaan merupakan rasio yang menunjukkan berapa kali jumlah barang sediaan diganti dalam satu tahun. Semakin kecil rasio ini, semakin buruk demikian pula sebaliknya.

Adapun menurut Hery (2015) menyatakan bahwa: Rasio ini menunjukkan kualitas persediaan barang dagang dan 
kemampuan manajemen dalam melakukan aktivitas penjualan. Dengan kata lain, rasio ini menggambarkan seberapa cepat persediaan barang dagang berhasil dijual kepada pelanggan.

Sedangkan perputaran persediaan menurut Munawir (2015) yaitu: Merupakan rasio antara jumlah harga pokok barang yang dijual dengan nilai rata-rata persediaan yang dimiliki oleh perusahaan. Perputaran persediaan ini menunjukkan berapa kali jumlah persediaan barang dagangan diganti dalam satu tahun (dijual dan diganti). Untuk mengetahui rata-rata persediaan tersimpan dalam gudang dapat ditentukan dengan membagi jumlah hari-hari dalam satu tahun dengan turn over dari persediaan tersebut.

Menurut Jumingan (2009) "Perputaran persediaan (inventory turn over) menunjukkan berapa kali persediaan barang dijual dan diadakan kembali selama satu periode akuntansi"

Berdasarkan pendapat-pendapat tersebut, bahwa persediaan barang adalah suatu ukuran untuk mengetahui berapa kali persediaan barang rata-rata berputar dalam seuatu periode tertentu. Semakin perputaran persediaan yang rendah merupakan tanda dari persediaan yang berlebihan dan persediaan yang lambat peredarannya. Sebaliknya semakin tinggi perputaran persediaan, maka semakin efisein manajemen persediaan perusahaan.

\section{Profitabilitas}

Profitabilitas adalah kemampuan suatu perusahaan yang dicapai dalam satu periode tertentu. Penilaian profitabilitas merupakan laporan keuangan yang terdiri dari laporan laba rugi dan laporan neraca perusahaan. Kedua laporan keuangan tersebut akan ditentukan hasil sejumlah rasio dan selanjutnya rasio ini digunakan untuk menilai operasi perusahaan pada beberapa aspek tertentu. Analisis profitabilitas tujuannya untuk mengukur kemampuan perusahaan dalam memperoleh keuntungan atau laba, baik dalam hubungannya dengan modal sendiri, aset, maupun penjualan. Hasil profitabilitas ini dapat dijadikan gambaran ataupun tolak ukur dari keuntungan yang diperoleh dengan membandingkan investasi perusahaan dan hasil penjualan. Apabila perusahaan mampu untuk bersaing dengan perusahaan-perusahaan lainnya, menuntut perusahaan untuk dapat meningkatkan profitabilitas.

Menurut Munawir (2015) menyatakan bahwa "Profitabilitas adalah mengetahui besarnya tingkat laba yang diperoleh perusahaan dalam satu periode, dan mengetahui posisi laba perusahaan taun sebelumnya dan tahun sekarang". Adapun pengertian profitabilitas menurut Hery (2015) bahwa: "Profitabilitas adalah untuk mengukur seberapa besar jumlah laba bersih yang akan dihasilkan dari setiap rupiah dana yang tertanam dalam penjualan".

\section{Rasio Profitabilitas}

Rasio profitabilitas merupakan rasio untuk mencari keuntungan dalam menilai kemampuan perusahaan. Hal ini ditunjukan oleh penjualan dan pendapatan yang menghasilkan laba. Rasio ini menunjukkan tingkat efisiensi suatu perusahaan, sesuai yang di ungkapkan Irham Fahmi (2017) bahwa "Rasio ini mengukur efektivitas manajemen secara keseluruhan yang ditujukan oleh besar kecilnya tingkat keuntungan yang diperoleh dalam hubungaannya dengan penjualan maupun investasi".

Menurut Hery (2015) yang menyatakan bahwa:

Rasio profitabilitas merupakan rasio yang menggambarkan kemampuan perusahaan dalam menghasilkan laba melalui semua kemampuan da sumber daya yang dimilikinya, yaiyu yang berasal dari kegiatan penjualan, penggunaan aset, maupun penggunaan modal.

Sedangkan menurut Kasmir (2015:196) dijelaskan bahwa sebagai berikut: Rasio profitabilitas merupakan rasio untuk menilai kemampuan perusahaan dalam mencari 
keuntungan. Rasio ini juga memberikan ukuran tingkat efektivitas manajemen suatu perusahaan. Hal ini ditunjukan oleh laba yang dihasilka dari penjualan dan pendapatan investasi. Intinya adalah penggunnaan rasio ini menunjukkan efisiensi peusahaan.

Penggunaan rasio profitabilitas dapat dilakukan dengan membandingkan antara laporan keuangan neraca dan laba rugi. Tujuannya yaitu agar terlihat gambaran perkembangan perusahaan dalam waktu terntentu, baik mencari penyebab perusahaan tersebut, sekaligus mengetahui penurunan atau kenaikannya.

Menurut Kasmir (2015) Tujuan penggunaan rasio profitabilitas bagi perusahaan, maupun bagi pihak luar perusahaan yaitu: untuk mengukur atau menghitung laba yang diperoleh perusahaan dalam suatu periode tertentu; untuk menilai posisi laba perusahaan tahun sebelumnya dengan tahun sekarang; untuk menilai besarnya laba bersih sesudah pajak dengan modal sendiri; untuk mengukur produktivitas seluruh dana perusahaan yang digunakan baik modal pinjaman maupun modal sendiri; untuk mengukur produktivitas dari seluruh dana perusahaan yang digunakan bsik modal sendiri; dan tujuan lainnya.

\section{Jenis-Jenis Rasio Profitabilitas}

Menurut Kasmir (2005) Dalam praktiknya, jenis-jenis rasio profitabilitas yang dapat digunakan adalah: Profit margin (profit margins on sales), Return on investment (ROI), Return on Equity (ROE), Laba perlembar saham.

Menurut Herry (2012), jenis-jenis rasio profitabilitas yakni: Rasio tingkat pengembalian atas investasi, Rasio Kinerja Operasi, Rasio Pemanfaatan Aktiva.

Menurut James dan John (2005), Rasio profitabilitas terdiri atas dua jenis rasio yang menunjukkan profitabilitas dalam kaitanyya dengan penjualan dan rasio yang menunjukkan profitabilitas dalam kaitannya dengan investasi.

\section{METODE PENELITIAN}

Penelitian dilakukan pada Matahari Department Store Tbk yang bergerak di bidang industri fashion. Jenis dan sumber data yang digunakan yaitu data sekunder, yaitu data yang diperoleh secara tidak langsung dari situs www.idx.co.id dengan cara studi kepustakaan atau dari dokumendokumen yang sudah ada. Dapat dilakukan dengan mengkaji, meneliti, mempelajari data yang ada kaitannya dengan penelititan. Studi kepustakaan dilakukan agar peneliti ini mempelajari referensi jurnal-jurnal, bukubuku, peneliti harus menggunakan sumber aslinya dalam mengemukakan teori yang relevan dengan masalah yang akan dibahas. Kemudian Dokumentasi adalah bagian dari teknik pengumpulan data dengan cara mempelajari dokumen-dokumen dan juga menelaah, seperti visi misi perusahaan, laporan keuangan perusahaan profil perusahaan dan lain-lain.

Bertitik tolak dari masalah yang telah dikemukakan sebelumnya, maka dalam membahas dan menganalisis permasalahan penulis menggunakan metode deskriptif dengan pendekatan kuantitatif yakni penelitian yang dilakukan untuk mengetahui nilai variabel dengan pengumpulan data berupa angka tanpa perlu membandingkan satu variabel dengan variabel lainnya dan tanpa perlu menghubungkan dengan variabel lainnya, dimana variabel tersebut mengolah data dengan angka angka.

Dalam penelitian ini menggunakan perhitungan rasio perputaran persediaan (inventory turnover) dan rasio profitabilitas (net profit margin). Adapun rumus rasio perputaran persediaan (inventory turnover) yang digunakan dalam penelitian ini adalah sebagai berikut, menurut (Munawir 2015)

Perputaran Persediaan ( Inventory Turn Over)

$$
\text { Inventory Turn Over }=
$$

$$
\begin{gathered}
\text { Harga pokok penjualan } \\
\text { Rata-rata persediaan }
\end{gathered}
$$


Lamanya rata-rata persediaan $=$

365 hari

Perputaran persediaan

Rumus rasio profitabilitas yang digunakan dalam penelitian ini adalah sebagai berikut, Menurut Hery (2015):

Margin Laba Bersih (Net Profit Margin) = . ow,

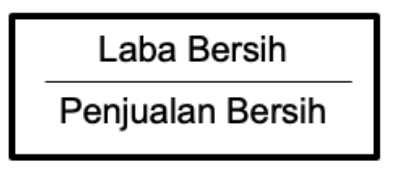

\section{HASIL DAN PEMBAHASAN}

Semakin tinggi rasio perputaran persediaan menunjukkan persediaan barang dagang dalam gudang semakin sedikit artinya semakin baik bagi perusahaan yang berarti penjualan meningkat sehingga, akan berpengaruh pula terhadap peningkatan kemampuan perusahaan dalam menghasilkan laba atau yang disebut profitabilitas dan sebaliknya. Berikut ini terdapat data rata rata persediaan, penjualan, harga pokok, serta laba bersih untuk dapat mengetahui perputaran persediaan dan tingkat profitabilitas Matahari Department Store Tbk yang ditampilkan dalam Tabel 1.

Berdasarkan tabel 1 diketahui bahwa adanya penurunan pada rata rata persediaan dari tahun 2016 sebesar Rp 1,010,426 (dalam ribuan rupiah) ke tahun 2017

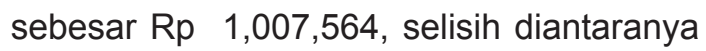
berkisar Rp. 2,826 (dalam ribuan rupiah). Lalu adanya fluktuasi pada penjualan yang di tahun 2014 mengalami penurunan penjualan dan di tahun 2015 hingga 2017 terus mengalami kenaikan kembali.

Selanjutnya berikut tabel 2 perputaran persediaan, dan profitabilitas dari Matahari Department Store Tbk.

Tabel 1. Persediaan Awal, Persediaan Akhir, Rata - Rata Persediaan, Penjualan, HPP, dan Laba Bersih

\begin{tabular}{|c|c|c|c|c|c|}
\hline & 2013 & 2014 & 2015 & 2016 & 2017 \\
\hline Pers. Awal & Rp 526,269 & Rp 729,691 & $\operatorname{Rp} 961,113$ & Rp 1,016,693 & $\operatorname{Rp} 1,004,158$ \\
\hline Pers. Akhir & Rp 729,691 & Rp 961,113 & $\operatorname{Rp} 1,016,693$ & Rp $1,004,158$ & Rp $1,010,969$ \\
\hline $\begin{array}{l}\text { Rata Rata } \\
\text { Persediaan }\end{array}$ & Rp 627,980 & Rp 845,402 & Rp 988,903 & Rp 1,010,426 & $\operatorname{Rp} 1,007,564$ \\
\hline Penjualan & Rp $6,754,326$ & Rp $4,898,745$ & Rp $5,729,126$ & $\operatorname{Rp} 9,897,046$ & Rp 10,023,961 \\
\hline HPP & $\operatorname{Rp} 2,391,274$ & $\operatorname{Rp} 2,877,507$ & $\operatorname{Rp} 3,335,638$ & $\operatorname{Rp} 3,685,279$ & $\operatorname{Rp} 3,762,021$ \\
\hline Laba Bersih & Rp $1,150,160$ & Rp $1,419,118$ & Rp $1,780,848$ & Rp 2,019,705 & $\operatorname{Rp} 1,907,077$ \\
\hline
\end{tabular}

Tabel 2. Hasil Penelitian

\begin{tabular}{|c|c|c|c|c|c|}
\hline & 2013 & 2014 & 2015 & 2016 & 2017 \\
\hline \multicolumn{6}{|l|}{ Perputaran } \\
\hline Persediaan & 3.81 & 3.40 & 3.37 & 3.65 & 3.73 \\
\hline \multicolumn{6}{|l|}{ Waktu } \\
\hline \multicolumn{6}{|l|}{ Perputaran } \\
\hline Persediaan & 95.85 & 107.24 & 108.21 & 100.08 & 97.76 \\
\hline Profitabilitas & 0.48 & 0.49 & 0.53 & 0.54 & 0.50 \\
\hline Persentase & 48.09 & & & & 50.69 \\
\hline Profitabilitas & $\%$ & $49.31 \%$ & $53.38 \%$ & $54.8 \%$ & $\%$ \\
\hline
\end{tabular}


Berdasarkan perhitungan tabel 2 tersebut dapat diketahui bahwa perputaran persediaan dari tahun 2013 sampai 2015 terus mengalami penurunan, kemudian ditahun 2015 sampai dengan 2017 mengalami kenaikan perputaran persediaan. Ini disebabkan karena penjualan Matahari Department Store Tbk juga mengalami fluktuasi dengan penurunan dan kenaikan di tahun yang sama. Yakni dari tahun 2013 hingga 2015 mengalami penurunan dan dari tahun 2015 hingga 2017 mengalami kenaikan. Selisih perputaran persediaan yang menunjukkan penurunan ditahun 2013 ke 2014 sebesar 0,41, ditahun 2014 ke 2015 sebesar 0,03 .

Profitabilitas dari tahun 2013 sampai tahun 2016 terus mengalami peningkatan, akan tetapi pada tahun 2016 ke tahun 2017 ditemukan adanya penurunan profitabilitas dengan selisih 0,04. Dan dalam persentase profitabilitas yang mengalami penurunan memiliki selisih dari tahun 2016 ke tahun 2017 sebesar $4,11 \%$. Perputaran persediaan yang mengalami fluktuasi ini menunjukkan bahwa perusahaan Matahari Department Store Tbk belum efisien dalam penyediaan persediaannya.

\section{SIMPULAN}

Berdasarkan penelitian yang telah dilakukan di Matahari Department Store Tbk. bahwa perputaran persediaannya di tahun 2013 sebesar 3,81, di tahun 2014 sebesar 3,40, di tahun 2015 sebesar 3,37, di tahun 2016 sebesar 3,65, ditahun 2017 sebesar 3,73 . Perputaran persediaan dari tahun 2013 sampai 2015 terus mengalami penurunan, kemudian ditahun 2015 sampai dengan 2017 mengalami kenaikan perputaran persediaan. Ini disebabkan karena penjualan Matahari Department Store Tbk juga mengalami fluktuasi dengan penurunan dan kenaikan di tahun yang sama. Yakni dari tahun 2013 hingga 2015 mengalami penurunan dan dari tahun 2015 hingga 2017 mengalami kenaikan.

Perputaran persediaan yang mengalami fluktuasi ini menunjukkan bahwa perusahaan Matahari Department Store Tbk belum efisien dalam penyediaan persediaannya. Kenyataan ini juga didukung oleh tingkat profitabilitas yang mengalami penurunan pada tahun 2016 ke tahun 2017 dengan selisih 0,04. Dan dalam persentase profitabilitas yang mengalami penurunan memiliki selisih dari tahun 2016 ke tahun 2017 sebesar $4,11 \%$.

\section{SARAN}

Semestinya pihak perusahaan agar meningkatkan laba yang mengalami penurunan yang terjadi pada tahun 2017 pada perusahaan Matahari Departement Store Tbk. Karena semakin besar hasil perputaran persediaan maka perputaran persediaan terhadap laba juga semakin meningkat.

Hasil perputaran persediaan pada tahun 2013 hingga 2015 perlu di tingkatkan, hal ini dapat dilakukan dengan meningkatkan jumlah penjualan, sehingga dengan volume penjualan yang tinggi, maka tingkat perputaran persediaan juga semakin tinggi, dan hal ini dapat meningkatkan profitabilitas atau laba perusahaan Matahari Departement Store Tbk semakin baik.

Bagi peneliti selanjutnya, agar mencari lebih banyak faktor-faktor lain yang dapat meningkatkan profitabilitas atau laba perusahaan, karena masih banyak variabelvariabel lain yang dapat berpengaruh dalam meningkatkan profitabilitas perusahaan. 


\section{REFERENSI}

Adawia, P. R. (2017). Analisis pengaruh perputaran persediaan terhadap profitabilitas perusahaan pada PT. Indocement Tunggal Prakasa Tbk.

Alexandri, M. B. (2009). Manajemen Keuangan Bisnis Teori dan Soal. Bandung: Alfabeta.

Atmaja, L. S. (2008). Teori Dan Praktik Manajemen Keuangan Yogyakarta: Andi

Herry. (2012). Analisis Laporan Keuangan. Jakarta: Bumi Aksara

Hery. (2015). Analisis Laporan Keuangan. Yogyakarta: CAPS (Capital for Academic Publishing Service) .

idx.co.id. (2018, November Senin). Retrieved from

https://www.idx.co.id/perusahaan-tercatat/laporan-keuangan-dan- tahunan/

Fahmi, I. (2017). Analisis Laporan Keuangan. Bandung: ALFABETA, CV.

Fahmi, I. (2012). Manajemen Investasi. Bandung: Salemba Empat.

Harahap, S. S. (2016). Analisis Kritis Atas Laporan Keuangan. Jakarta: Rajawali.

Harmono. (2011). Manajemen Keuangan. Jakarta: Bumi Aksara.

James C Van Horne dan John M. Wachowicz, J. (2005). Financial Management-Prinsip Prinsip Manajemen Keuangan. Jakarta: Salemba Empat.

Janrosl, V. S. (2015). Pengaruh inventory turnover, total asset turnover dan net profit margin terhadap perubahan laba pada perusahaan manufaktur yang terdaftar di bursa efek indonesia.

Jumingan. (2009). Analisis Laporan Keuangan. Jakarta: Bumi Aksara

Kasmir, D. (2012). Analisis Laporan Keuangan. Jakarta: PT Raja Grafindo Persada

Kasmir. (2015). Analisis Laporan Keuangan. Jakarta: PT. Raja Grafindo Persada.

Kemenperin.go.id. (2018, November Senin). Retrieved from

http://www.kemenperin.go.id/artikel/19435/Kinerja-Industri-Kosmetik-Nasional-LampauiPertumbuhan- Ekonomi

Mulatsih. (2014). Analisis tingkat perputaran persediaan, tingkat perputaran modal kerja dan tingkat perputaran kas terhadap profitabilitas pada perusahaan sektor kimia yang terdaftar di BEl.

Munawir. (2002). Analisis Laporan Keuangan. Yogyakarta: Liberty.

Munawir. (2015). Analisis Laporan Keuangan. Yogyakarta: Liberty

Setiawan, I. (2014). Pengaruh current ratio, inventory turnover, time intereset earned dan return on equity terhadap harga saham pada perusahaan manufaktur sektor barang konsumsi yang terdaftar di Bura Efek Indonesia 2009-2012.

Sugiyono. (2012). Metode Penelitian Bisnis. Bandung : Alfabeta.

Widodo, A. (2012). Pengaruh current ratio, inventory turnover, receivable turnover terhadap pertumbuhan profitabilitas pada PT. Hero Supermarket, Tbk. 